\title{
A Universal Social Minimum - Half-baked 'Apple Pie in the Sky'? A Reply to Sabates-Wheeler and Devereux
}

\author{
Koy Thomson
}

American soldiers, when asked why they were fighting in World War II, were said to reply 'for mom and apple pie' - both being unassailable American virtues, impossible to argue against. The universal social minimum is far from being accepted as 'apple pie', particularly in the land where this phrase originated. It would be hard to find a country with an equal hostility to welfare, benefits and social protection. The same applies to many other countries, poor or rich. Having had many discussions with government officials and even NGO colleagues, it is clear that there the predominant mood is to blame the poor for their own condition and that providing 'handouts' or letting people 'get something for nothing' will just make things worse. When you get down to policy detail you should not underestimate the depth of anti-poor prejudice. So the universal social minimum is far from 'apple pie'.

Is it 'pie in the sky' in the sense of enduring suffering in this life with a promise to be fed in the afterlife? This was how Joe Hill, the radical songwriter, labour activist and member of the 'wobblies' coined the phrase 'pie in the sky' as a satire of a Salvation Army song. I would like to think that the universal social minimum is the opposite, something that Joe Hill would have fought for.

But what of the last part of the mixed metaphor 'half-baked'? On this yes, the idea is half-baked, and deliberately so. It is critical that the idea is shaped and debated by citizens and governments in particular contexts and as a constitutive part of developing responsive and just governance. I think people have had enough of having 'over-baked' ideas shoved down their throats.

I am puzzled why the reviewers associate the idea of a universal social minimum with communist and socialist states. What characterises these states are things like state-controlled planned economies, collectivisation, lack of private property and markets, bouffant hairstyles and eternal presidents. There may well be greater emphasis on social and economic rights, but these play little part in the core political dynamics. I rather associate the ideals behind the social minimum with William Beveridge and Franklin D. Roosevelt. The universal social minimum is not associated with any particular political philosophy. Indeed arguments in its support could be found from egalitarian, communitarian and libertarian perspectives.

The reviewers raise some very interesting points on inequality. Is some level of inequality a good thing for 'pro-poor' growth? The social minimum is not an ideological levelling down so that it is impossible to give anyone a hand up. In part, it does have an evaluative function so that we can better understand where people do need a hand up. Ideologically it does contain a belief that structural inequality, which makes and keeps people vulnerable to poverty, is a moral problem. In this sense, I would disagree with the reviewers that the inequalities and inequities that matter for the poor are 'to a large degree an empirical question'. But the policy response - putting the social minimum into practice - will require careful consideration of empirical evidence. This is 
where the question of the link between opportunities (income, assets, land) and income growth is key.

What is the ultimate vision of the social minimum? Is it equality of opportunities or equality of outcomes? The social minimum is not social justice fulfilled. But it goes beyond addressing the brute material deprivations to provide a floor of dignity and a basic standard of living so that materially and politically, people are in a position to plan and pursue their own goals and as citizens shape their vision of society with others. It is really up to them whether they want to pursue equality of outcomes, communism or turbo-capitalism. To get to this point will require a basic equality of distribution of resources, goods, services, rights, power and opportunities. This in essence is the thinking behind international human rights standards. The mix and level is something that will be determined according to politics, citizen demand and empirical evidence.

All of this is to be realised progressively according to the 'resource envelope'. But it has long been civil society's major struggle to push the resource envelope (nationally and globally) and argue for priorities within it.

Social protection should be a guarantee and not based upon discretion and charity. But this is not to say that other sources of value than rights are not relevant and important, whether these are 'duty', 'love', 'compassion', 'care', or 'solidarity'.

For anyone who has been at all involved in national policy processes around social protection it is striking how technocratic and alienated from the mainstream of political imagination and debate the issue has become. Parliamentarians, civil society organisations, the media and the public do not understand social protection and so are not getting involved. Social protection advocates should be heralding in a revolution, helping those involved in poverty and development to understand what human rights and social justice principles mean in practice - what they look like in a political programme. This is the ground that the universal social minimum aims to cover. Will it be possible to develop a political constituency around the universal social minimum? In South Africa the Basic Income Grant campaign was the biggest post-apartheid civil society mobilisation. There is a growing global network of progressive social protection advocates, the ILO's campaign for decent work includes social protection, and there are proposals for a Campaign for Universalising Social Protection. Globally and nationally, civil society lacks a conceptually coherent platform around which to frame national and international policy engagement. The universal social minimum could provide just such a platform. 